\title{
Efficiency of Aluminium and Copper Coated Aluminium Electrode in Hydrogen Fuel Generation from Rain Water
}

\author{
Md. Khalid Saklin1, Rajib Chandra Das ${ }^{*}$, Yeasmin Akther1, Sanchita Dewanjee1, \\ Sujan Kanti Das ${ }^{2}$, Tania Sabnam Binta Monir ${ }^{1}$, Susmita Mondal ${ }^{3}$ \\ ${ }^{1}$ Department of Applied Chemistry and Chemical Engineering, Noakhali Science and Technology University, Noakhali, \\ Bangladesh \\ ${ }^{2}$ Bangladesh Council of Scientific and Industrial Research, Chattogram, Bangladesh \\ ${ }^{3}$ Department of Pharmacy, Noakhali Science and Technology University, Noakhali, Bangladesh \\ Email: *rajib.acce@gmail.com
}

How to cite this paper: Saklin, Md.K., Das, R.C., Akther, Y., Dewanjee, S., Das, S.K., Monir, T.S.B. and Mondal, S. (2020) Efficiency of Aluminium and Copper Coated Aluminium Electrode in Hydrogen Fuel Generation from Rain Water. Energy and Power Engineering, 12, 348-356.

https://doi.org/10.4236/epe.2020.126021

Received: March 14, 2020

Accepted: June 16, 2020

Published: June 19, 2020

Copyright $\odot 2020$ by author(s) and Scientific Research Publishing Inc. This work is licensed under the Creative Commons Attribution International License (CC BY 4.0).

http://creativecommons.org/licenses/by/4.0/

(c) (i) Open Access

\begin{abstract}
Water electrolysis is considered as the most capable and old technology for hydrogen fuel preparation. Electrolysis needs external electrical energy through electrodes to split water into hydrogen and oxygen. An efficient electrolysis requires suitable electrodes to minimize potential drop. In this study Aluminium and Copper Coated Aluminium were used as different combination of Anodes and Cathodes to find out more efficient electrodes combination. $\mathrm{NaCl}$ solution in rain water was taken as electrolyte. Rain water was taken to avoid ionic impedance of tap water and expenses of distilled water. In this study, the most efficient electrode combination was Copper Coated Aluminium (anode)-Aluminium (cathode) and gave the highest efficiency of hydrogen production to about $11 \%$ at normal temperature for very low concentration of $\mathrm{NaCl}(0.051 \mathrm{M})$ which increased with temperature, up to $29 \%$ upon rising of temp to $60^{\circ} \mathrm{C}$. It was showed that higher concentration of electrolyte would surge the efficiency significantly. If the supplied heat could be provided from any waste heat sources then this study would be more efficient. However, current research evaluated the technical feasibility of this electrode combination for producing hydrogen with electrolysis of rain water utilizing electricity and modified electrodes.
\end{abstract}

\section{Keywords}

Hydrogen Production, Electrochemistry, Water Electrolysis, Copper Coated Aluminum, Rain Water 


\section{Introduction}

Hydrogen fuel is considered the cleanest alternative fuel to face world's energy challenge which leads researchers to fulfill increasing global energy demand using more economical and environmentally-friendly ways [1]. Hydrogen is an important source of sustainable energy system which can be a promising alternative energy for carbon-based fuel [2] [3]. It is safe as other commonly used fuels for future due to free emissions of COx, NOx and SOx and its highest heating value $(-286 \mathrm{~kJ} / \mathrm{mol})$ as well as economic consideration [4] [5] [6]. Hydrogen can also be stored in compressed $\mathrm{H}_{2}$ tanks and liquefied by adsorption [5].

Electrolysis of water is one of the most primitive and capable methods for production of hydrogen [7]. Water is the world's most widely-available natural resources which on electrolysis produced only pure oxygen as by-product [3] [8] [9]. Electrolysis gives hydrogen at $\mathbf{9 9 . 9 9 \%}$ purity compared with the hydrogen obtained from other greenhouse gas emitting sources like fossil fuels [10].

Electrolysis process has been trailing behind due to expensive electrolytic system. External power sources cost a larger portion of a cell. Electrodes are the main constituent of an electrolytic cell and the most sensitive part of a cell needed extensive care during selection and preparation of suitable electrodes [8]. Potential loss occurring between electrodes is greatly responsible to lower the efficiency of an electrolytic cell. Research to get a plausible electrodes combination in terms of cost and efficacy always gets researchers keen. Recently Ni, Co, Cu, $\mathrm{Pt}, \mathrm{Fe}$ etc. and their alloys, oxides, and bi-metal coatings are being efficiently used as electrode constructing materials [11] [12]. Most of these materials are very expensive and require high degree of purity (99.99\%). As a consequence scope is still there to work for getting more compatible electrode combinations.

Current study was intended to prepare a new suitable efficient electrode combination at minimum expense. Though Aluminium is very reactive, it is cheap and available and it can be amenable to be coated by another metal to prepare metal clad. The process based on the anodic dissolution of coated and uncoated aluminum combination [1] in alkaline-chloride solutions in rain water is one of the research areas that study the new ways of electrochemical hydrogen production along with its efficiency measurement [9].

\section{Experimental}

\subsection{Materials}

Rain water was collected from Noakhali, Bangladesh after two days of rain. All chemicals (copper sulphate, sulphuric acid, hydrochloric acid and sodium chloride) used in this study were purchased from MERCK, Germany. Aluminium sheet and Copper wire for electrodes were purchased from local market.

\subsection{Methods}

\subsubsection{Preparation of Aluminium Electrode from Aluminium Sheet}

Aluminium sheet commercially known as aluminium alloy 1100 (i.e. $99 \% \mathrm{Al}$ and 
traces of $\mathrm{Si}, \mathrm{Fe}, \mathrm{Cu}, \mathrm{Mn}, \mathrm{Zn}$ and others) was purchased from local market [13]. It was then cut into $127 \mathrm{~mm}$ in length, $13 \mathrm{~mm}$ in width and thickness was maintained $1.2 \mathrm{~mm}$ exactly, polished with grinder polisher and thoroughly washed by distilled water to remove adhering dust or debris and then dried in open air.

\subsubsection{Electroplating on Aluminium by Copper Solution}

Classical electroplating principle was used to coat aluminium with copper. Current was supplied from a DC power supply $(12 \mathrm{v})$ in a cell containing $0.5 \mathrm{M}$ copper sulphate solution, copper wire was used as anode. After passing current for about 5 - 10 minutes, electroplating was done. Electroplated plates were then firmly rinsed with water and dried at room temperature.

\subsubsection{Electrolysis Procedure}

Simple electrolysis of rain water with varying concentration $(0.034 \mathrm{M} ; 0.051 \mathrm{M}$; $0.068 \mathrm{M} ; 0.086 \mathrm{M}$ ) of electrolyte, $\mathrm{NaCl}$ was carried out by supplying DC voltage. Four different easily available combinations of anode and cathode were used to choose the more efficient electrodes combination for this study, these were aluminium and aluminium (Al-Al), aluminium and $\mathrm{Cu}$ coated aluminium ( $\mathrm{Al}-\mathrm{Cu}(\mathrm{Al})$ ), $\mathrm{Cu}$ coated aluminium and aluminium $(\mathrm{Cu}(\mathrm{Al})-\mathrm{Al})$ and $\mathrm{Cu}$ coated aluminium and $\mathrm{Cu}$ coated aluminium electrodes $(\mathrm{Cu}(\mathrm{Al})-\mathrm{Cu}(\mathrm{Al}))$, first one is anode and second one is cathode in every combination. Electrodes were connected to external DC voltage supply. Two different measuring cylinders filled with water were kept in a way over the electrodes that product of electrolysis can be collected by the downward replacement of water in the cylinder (Figure 1) [10]. Stopwatch was carefully used for recording time and volume of the hydrogen gas was measured by measuring cylinder. Hydrogen production rate (HPR) was

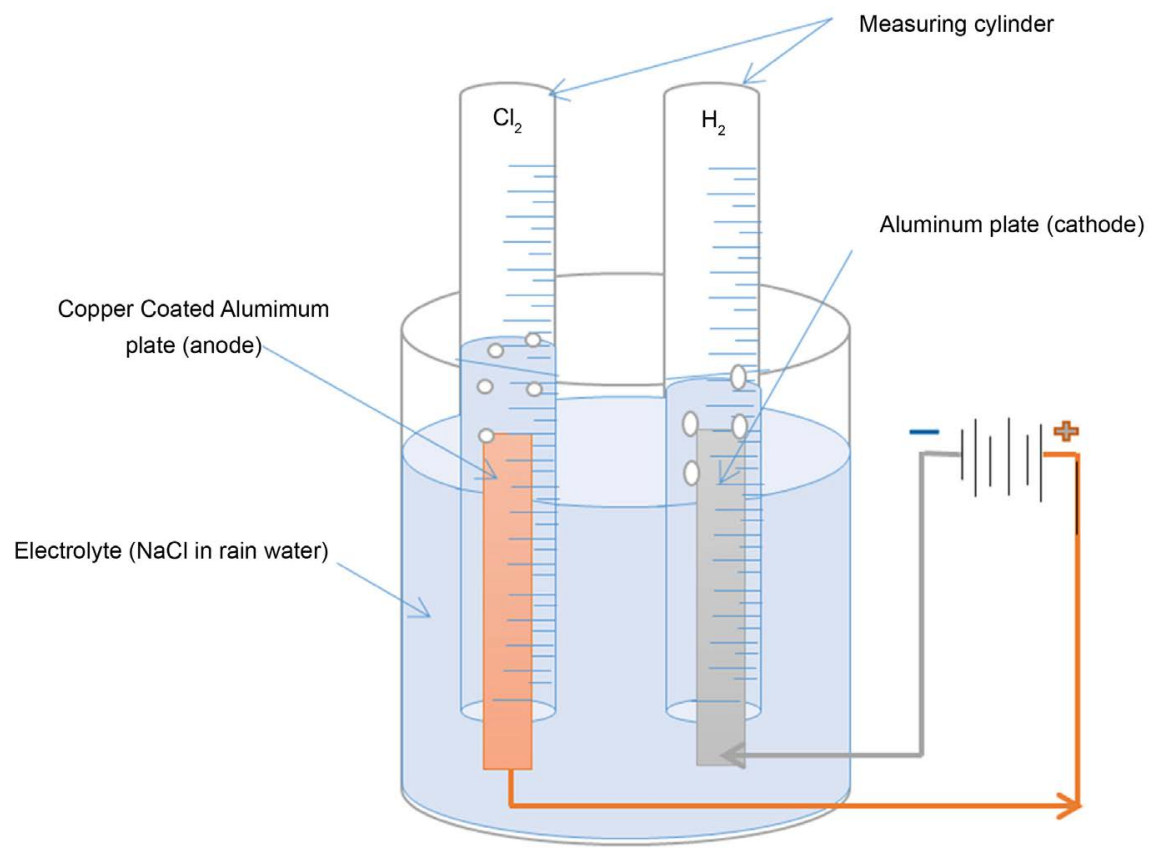

Figure 1. Schematic diagram of electrolytic cell using $\mathrm{Cu}$ coated $\mathrm{Al}$ anode and $\mathrm{Al}$ cathode. 
calculated as $\mathrm{cc} / \mathrm{min}$. To investigate the effect of temperature the beaker was kept in a hot plate and the temperature was raised $5^{\circ} \mathrm{C}$ each time and HPR is measured accordingly.

\subsubsection{Electrolysis Efficiency}

The efficiency of electrolysis can be defined as the ratio of chemical energy of hydrogen produced to the energy input for electrolysis process. There are a number of expressions for calculating electrolysis efficiency $(\eta)$ [14] [15]. In this study, electrical energy was used to get chemical energy; therefore, efficiency was calculated by using mass flow rate of hydrogen and enthalpy with respect to electrical energy.

$$
\eta=\frac{Q H}{V I}
$$

where, $\eta$ is the efficiency (\%), $Q$ is the mass flow rate of hydrogen $(\mathrm{kg} / \mathrm{sec}), H$ is the enthalpy of combustion of hydrogen $(\mathrm{J} / \mathrm{kg}), V$ is the applied voltage (Volt), and $I$ is the current $(\mathrm{A})$.

\section{Results and Discussion}

\subsection{Physical Properties of Water}

Water for different purposes has its own requirements as to composition and purity. Hence, water quality assessment involves analysis of physical, chemical, biological and microbiological parameters. Here, the physical parameters such as $\mathrm{pH}$, electric conductivity, salinity, total dissolved solid (TDS) of rain water were analyzed and tabulated in Table 1.

Result shows that rain water possesses tolerable $\mathrm{pH}$ and salinity. Mean value of conductivity $(0.4 \mathrm{mS} / \mathrm{cm})$ and TDS $(22 \mathrm{ppm})$ indicates that rain water contains less interfering particles responsible for lowering the efficiency of the cell, as it is evident that conductivity decreased with TDS [16] and TDS decrease the cell efficiency.

$$
\mathrm{TDS}=765.1 \mathrm{EC}^{1.087}
$$

\subsection{Suitable Electrodes Selection}

Four different electrode combinations were used for electrolysis of $\mathrm{NaCl}$ solution (Figure 2).

Result shows that, $\mathrm{Cu}(\mathrm{Al})-\mathrm{Al}$ combination of electrodes showed higher hydrogen

Table 1. Physical properties of rain water.

\begin{tabular}{ccccc}
\hline Sl. No. & Ph & Salinity (\%) & Conductivity (mS/cm) & TDS (ppm) \\
\hline 1 & 6.9 & 3 & 0.03 & 22 \\
2 & 6.7 & 3 & 0.04 & 23 \\
3 & 6.8 & 3 & 0.05 & 21 \\
Mean value & 6.8 & 3 & 0.04 & 22 \\
\hline
\end{tabular}




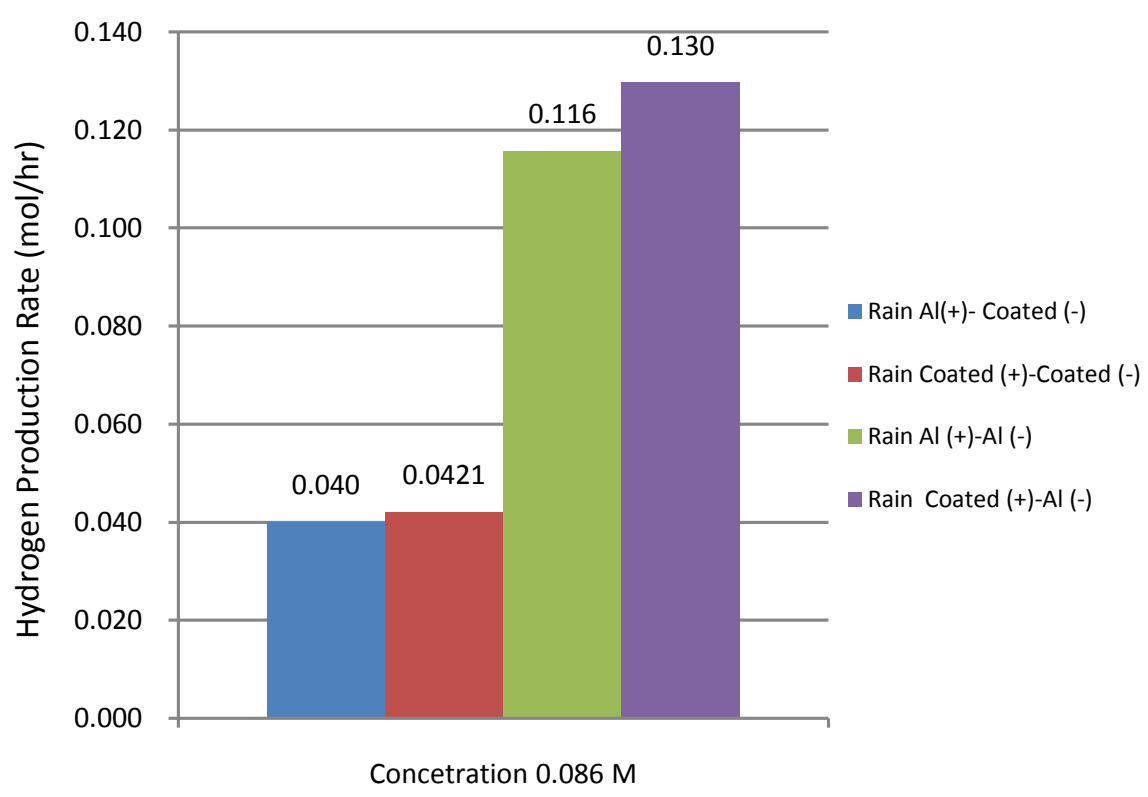

Figure 2. Hydrogen production rate on tap water and rain water at different combination of electrodes.

production rate than three other electrodes combination. These electrodes combination can be arranged in the order of increasing rate of hydrogen production as:

$$
\mathrm{Al}-\mathrm{Al}<\mathrm{Cu}(\mathrm{Al})-\mathrm{Cu}(\mathrm{Al})<\mathrm{Al}-\mathrm{Al}<\mathrm{Cu}(\mathrm{Al})-\mathrm{Al}
$$

Maximum hydrogen production $(0.130 \mathrm{~mol} / \mathrm{hr})$ was found when rain water was electrolysed by $\mathrm{Cu}(\mathrm{Al})-\mathrm{Al}$ electrode combination. $\mathrm{Al}-\mathrm{Al}$ electrodes held the second position $(0.116 \mathrm{~mol} / \mathrm{hr})$. Whereas, $\mathrm{Cu}(\mathrm{Al})-\mathrm{Cu}(\mathrm{Al})$ didn't give satisfactory rate and $\mathrm{Al}-\mathrm{Cu}(\mathrm{Al})$ gave least value of production rate $(0.040 \mathrm{~mol} / \mathrm{hr})$.

$\mathrm{Cu}(\mathrm{Al})-\mathrm{Al}$ electrode acted as the most sensitive electrode combination. It can be best described by the basic knowledge of electrical properties of aluminium and copper. Conductivity of pure copper at $20^{\circ} \mathrm{C}, 5.96 \times 10^{7} \mathrm{~S} / \mathrm{m}$ [17] is much higher than the conductivity of pure aluminium, $3.77 \times 10^{7} \mathrm{~S} / \mathrm{m}$ at $20^{\circ} \mathrm{C}$ [18]. It is seen that, copper coating on aluminium increase the conductivity of this hybrid material as happened to copper clad aluminium wire [19]. According to Elektrisola Group, a renowned enameled wire manufacturing company, the conductivity of their product CCA15\% (15\% Copper Clad Aluminium) is 3.915 $\times 10^{7} \mathrm{~S} / \mathrm{m}$, slightly higher than pure aluminium [20]. For this reason, there arises an innate potential difference between anode and cathode compared to the rest of the electrode combinations in this study. This potential difference is responsible for the maximum production rate at this condition.

\subsection{Effect of Electrolyte Concentrations on Hydrogen Production}

A greater number of effective ionic collisions per unit time were occurred by increasing electrolytic concentration and as a result reaction rate as well as efficiency increased with increasing electrolytic concentration [5]. A number of stu- 
dies suggest that, hydrogen production rate increase with the strength of electrolyte used [21] [22].

In this study concentration of electrolyte was gradually varied from 0.034 to $0.086 \mathrm{M}$ and consequently hydrogen production rate increased linearly with electrolyte concentration. HPR $(0.131 \mathrm{~mol} / \mathrm{hr})$ found maximum for $0.086 \mathrm{M}$ and similarly efficiency found $16 \%$ for the highest concentration of electrolyte (Table 2 \& Figure 3 ).

\subsection{Effect of Temperature on Hydrogen Production}

It is well established that HPR efficiency increases with temperature [23]. Current study analysed temperature effect on electrolysis of $0.051 \mathrm{M}$ aqueous solution of $\mathrm{NaCl}$ and found that HPR increased with temperature, tabulated in Table 3. At room temperature efficiency measured $11 \%$ but it rose sharply up to $29 \%$ at $60^{\circ} \mathrm{C}$. Ionic conductivity of an electrolyte rises directly with rising temperature. When temperature is high, less energy is required to reach any given current density compared to low temperature process. Moreover, surface reaction of any electrolyte was also directly affected by changing temperature [5]. The more the temperature, the surface reaction of electrolytes would be more appreciable. Hence, temperature was the most important variables on the electrolytic cell.

Table 2. Hydrogen production rate with varying electrolyte concentrations.

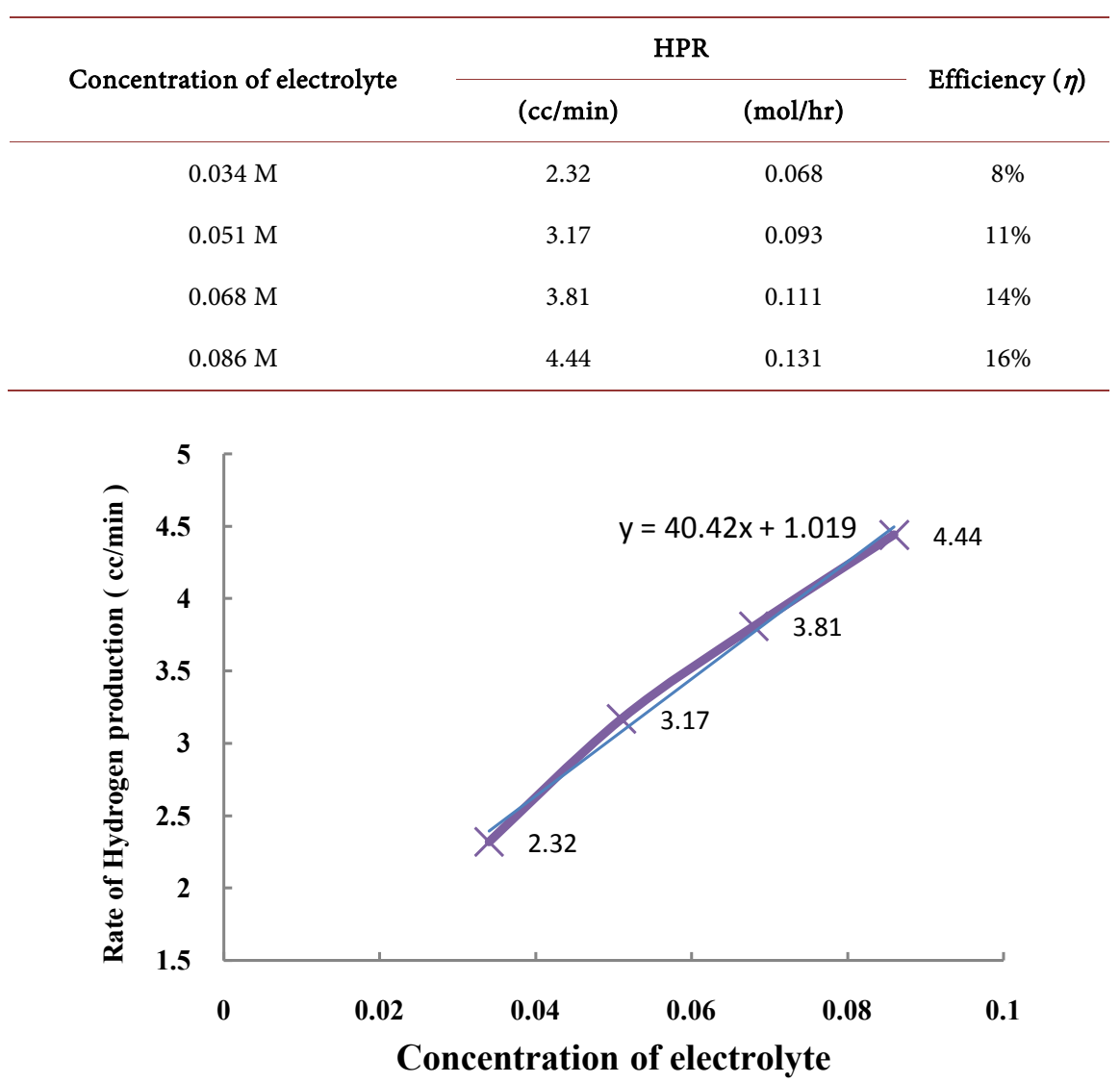

Figure 3. Effect of electrolyte concentrations on hydrogen production. 
Table 3. Hydrogen production with increasing of temperature.

\begin{tabular}{cccc}
\hline \multirow{2}{*}{ Temperature $\left({ }^{\circ} \mathrm{C}\right)$} & \multicolumn{2}{c}{ HPR } & Efficiency $(\boldsymbol{\eta})$ \\
\cline { 2 - 3 } & $(\mathrm{cc} / \mathrm{min})$ & $(\mathrm{mol} / \mathrm{hr})$ & $11 \%$ \\
\hline At room temperature & 3.17 & 0.093 & $22 \%$ \\
40 & 54 & 1.58 & $24 \%$ \\
45 & 58 & 1.71 & $25 \%$ \\
50 & 60 & 1.75 & $27 \%$ \\
55 & 65 & 1.91 & $29 \%$ \\
60 & 71 & 2.08 & \\
\hline
\end{tabular}

\section{Conclusion}

This work showed an additional value of used coated aluminum electrode combinations for the hydrogen production through electrolysis using $\mathrm{NaCl}$ electrolyte in rain water. Experimental data showed that Copper Coated Aluminium (anode)-Aluminium (cathode) combination produced much hydrogen than other combinations of electrodes used in the current study. Preparations of these electrodes require trivial effort and cost, making it easy to use in the electrolytic cells. But, this study didn't have any storage facilities for hydrogen gas. Hydrogen production efficiency was proportional to supplied energy; here efficiency increased with temperature. Waste heat energy from various human activities can be used for the input temperature used at the current studies, and needs extensive future research work.

\section{Conflicts of Interest}

The authors declare that there is no conflict of interests regarding the publication of this paper.

\section{References}

[1] Bairachnyi, V., Rudenko, N., Zhelavska, Y. and Pilipenko, A. (2019) Using Aluminum Alloys in the Electrochemical Hydrogen Production. Materials Today. Proceedings, 6, 299-304. https://doi.org/10.1016/j.matpr.2018.10.108

[2] Kumar, S.S. and Himabindu, V. (2019) Hydrogen Production by PEM Water Electrolysis: A Review. Materials Science for Energy Technologies, 2, 442-454. https://doi.org/10.1016/j.mset.2019.03.002

[3] Miyaoka, H., Miyaoka, H., Ichikawa, T., et al. (2018) Highly Purified Hydrogen Production from Ammonia for PEM Fuel Cell. International Journal of Hydrogen Energy, 43, 14486-14492. https://doi.org/10.1016/j.ijhydene.2018.06.065

[4] Kelly, N.A., Gibson, T.L., Cai, M., Spearot, J.A. and Ouwerkerk, D.B. (2009) Development of a Renewable Hydrogen Economy-Optimization of Existing Technologies. IMETI 2009-2nd Int. Multi-Conference Eng. Technol. Innov. Proc., 1, 128-135.

[5] Yuvaraj, A.L. and Santhanaraj, D. (2014) A Systematic Study on Electrolytic Production of Hydrogen Gas by Using Graphite as Electrode. Materials Research, 17, 83-87. https://doi.org/10.1590/S1516-14392013005000153 
[6] Majumder, S.A. and Khan, S.U.M. (1994) Photoelectrolysis of Water at Bare and Electrocatalyst Covered Thin Film Iron Oxide Electrode. International Journal of Hydrogen Energy, 19, 881-887. https://doi.org/10.1016/0360-3199(94)90040-X

[7] Richards, J.W. (1896) Modern Theories of Electrolysis. Journal of the Franklin Institute, 141, 192-218. https://doi.org/10.1016/S0016-0032(96)90067-8

[8] Zikri, A., Erlinawati, Trisnaliani, L. and Wulandari, D. (2018) The Design of ACE (Aluminum Corrosion and Electrolysis) Reactor and Its Performance to Produce Hydrogen from Beverage Cans. Reaktor, 17, 210-214.

http://ejournal.undip.ac.id/index.php/reaktor/ https://doi.org/10.14710/reaktor.17.4.210-214

[9] Acar, C. and Dincer, I. (2018) Investigation of a Novel Photoelectrochemical Hydrogen Production System. Chemical Engineering Science, 197, 74-86. https://doi.org/10.1016/j.ces.2018.12.014

[10] Bockris, J.O’M., Dandapani, B., Cocke, D. and Ghoroghchian, J. (1985) On the Splitting of Water. International Journal of Hydrogen Energy, 10, 179-201. https://doi.org/10.1016/0360-3199(85)90025-4

[11] Zeng, K. and Zhang, D. (2010) Recent Progress in Alkaline Water Electrolysis for Hydrogen Production and Applications. Progress in Energy and Combustion Science, 36, 307-326. https://doi.org/10.1016/j.pecs.2009.11.002

[12] Hu, W., Cao, X., Wang, F. and Zhang, Y. (1997) Short Communication: A Novel Cathode for Alkaline Water Electrolysis. International Journal of Hydrogen Energy, 22, 441-443.

[13] Baumeister, T. and Avallone, E.A. (1978) Marks's Standard Handbook for Mechanical Engineers.

https://refacsmkn1crb.files.wordpress.com/2012/11/38102475-marks-standard-han dbook-for-mechanical-engineers.pdf

[14] Zhang, H., Lin, G. and Chen, J. (2010) Evaluation and Calculation on the Efficiency of a Water Electrolysis System for Hydrogen Production. International Journal of Hydrogen Energy, 35, 10851-10858. https://doi.org/10.1016/j.ijhydene.2010.07.088

[15] Ni, M., Leung, M.K.H. and Leung, D.Y.C. (2008) Energy and Exergy Analysis of Hydrogen Production by a Proton Exchange Membrane (PEM) Electrolyzer Plant. Energy Conversion and Management, 49, 2748-2756. https://doi.org/10.1016/j.enconman.2008.03.018

[16] Chang, C., Sommerfeldt, T.G., Carefoot, J.M. and Schaalje, G.B. (1983) Relationships of Electrical Conductivity with Total Dissolved Salts and Cation Concentration of Sulfate-Dominant Soil Extracts. Canadian Journal of Soil Science, 63, 79-86. https://doi.org/10.4141/cjss83-008

[17] Matula, R.A. (1979) Electrical Resistivity of Copper, Gold, Palladium, and Silver. Journal of Physical and Chemical Reference Data, 8, 1147-1298. https://doi.org/10.1063/1.555614

[18] Serway, R.A. and Jewett, J.W. (2003) Physics for Scientists and Engineers (with PhysicsNOW and InfoTrac). 6th Edition, Brooks Cole.

[19] Yamazaki, K. and Zimmerman, P.E. (1993) United States Patent (19).

[20] CCA15\% (n.d.). https://www.elektrisola.com/conductor-materials/aluminum-copper-clad-aluminu $\mathrm{m} / \mathrm{cca} 15 . \mathrm{html}$

[21] Buddhi, D., Kothari, R. and Sawhney, R.L. (2006) An Experimental Study on the Effect of Electrolytic Concentration on the Rate of Hydrogen Production. International Journal of Green Energy, 3, 381-395. 
https://doi.org/10.1080/01971520600873343

[22] Ben Slama, R. (2013) Production of Hydrogen by Electrolysis of Water: Effects of the Electrolyte Type on the Electrolysis Performances. Computational Water, Energy, and Environmental Engineering, 2, 54-58. https://doi.org/10.4236/cweee.2013.22006

[23] Kothari, R., Buddhi, D. and Sawhney, R.L. (2005) Studies on the Effect of Temperature of the Electrolytes on the Rate of Production of Hydrogen. International Journal of Hydrogen Energy, 30, 261-263. https://doi.org/10.1016/j.ijhydene.2004.03.030 